\title{
What drives 'soft deportation'? Understanding the rise in Assisted Voluntary Return among rejected asylum seekers in the Netherlands
}

\author{
Arjen Leerkes ${ }^{1}$ | Rianne van $\mathrm{Os}^{2}$ | Eline Boersema ${ }^{2}$
}

\author{
${ }^{1}$ Erasmus University Rotterdam and Research \\ and Documentation Centre, Rotterdam, The \\ Netherlands \\ ${ }^{2}$ Research and Documentation Centre, The \\ Hague, The Netherlands \\ Correspondence \\ Arjen Leerkes, Erasmus University Rotterdam \\ and Research and Documentation Centre, \\ Postbus 1738, 3000 DR Rotterdam, The \\ Netherlands. \\ Email: leerkes@fsw.eur.nl
}

\begin{abstract}
States experience difficulties in realizing the return of rejected asylum seekers, but migration control policies are becoming increasingly sophisticated. Against this background, we consider explanations for the increase in Assisted Voluntary Return from the Netherlands in the 2005-2011 period. Both macro-level factors (source country societal conditions and characteristics of the Dutch "deportation regime") and individual-level factors (applicants' demographic characteristics and variation in status determination time) are examined. The study, which is based on a unique multilevel dataset $(N=15,682)$ with data from governmental and other sources (including International Organisation for Migration), is the first to quantitatively test assumed Assisted Voluntary Return determinants and contributes to the study of policy effects in migration studies. We find that states are capable of increasing return rates by expanding the use of "hard" and "soft" power. We propose the term "soft deportation" as a way to go beyond the dichotomy of "voluntary" and "forced" return.
\end{abstract}

\section{KEYWORDS}

Assisted Voluntary Return, deportation, immigration regimes, policy effects, rejected asylum seekers, return migration

\section{1 | INTRODUCTION}

Rejected asylum seekers are normally asked to return to their country of citizenship, and their repatriation is an issue of significant concern in the industrialized world (Noll, 1999). In the European context, 'voluntary return' is preferred over 'forced return' and rejected asylum seekers are, in principle, first given the opportunity to organize their departure themselves, usually assisted by the International Organisation for Migration (IOM) (Baldaccini, 2009). In the case of Assisted Voluntary Return (AVR), the IOM pays the travel expenses and provides financial and/or other support. Rejected asylum seekers who do not leave are generally considered illegal aliens at some point, meaning that they become "deportable", and may be apprehended with a view to deportation

Countries experience difficulties in realizing the repatriation of rejected asylum seekers (Black et al., 2004; Ellermann, 2008; Noll, 1999; Leerkes \& Broeders, 2010), and the Netherlands is no exception. For example, out of all those who applied for asylum in 2001 and no longer had legal stay in 2007 , only $20 \%$ had 'demonstrably' left the country by 2007, that is, had left via AVR or deportation (INDIAC, 2007). The remaining $80 \%$ stayed illegally, or left without IOM involvement. The state does not register "non-assisted" departure, but the number of people leaving in this fashion seems to be limited. Information from a 2007 Amnesty program suggests that in the early 2000s, the average annual unregistered departure rate-including onward (illegal) migration to other European countries-was about 5\% to $10 \%{ }^{1}$ Unregistered departure may have decreased since then, as it has become more difficult for rejected asylum seekers to go to a different European country. ${ }^{2}$

There is disagreement in migration studies regarding the effectiveness of migration control (cf. Czaika \& De Haas, 2013; Lahav \& Guiraudon, 2006). A considerable body of research highlights limits to migration control. For example, Czaika and De Haas (2013: 497) point at "efficacy gaps", when "[p]olicy efficacy is constrained because migration is driven by structural determinants in origin and destination countries [and] internal dynamics of migration networks and systems." Other researchers argue that policies are becoming increasingly sophisticated. An example is Gibney's analysis of what he calls the 
"deportation turn"-the increased use of deportation in many western countries as a way of dealing with rejected asylum seekers and (other) deportable migrants: "states are adaptive agents, often able to modify their behavior to respond effectively to challenges to the exercise of border control" (Gibney, 2008: 152). While his analysis focuses on the ability of governments to partially overcome the limits of deportation as an instrument of migration control, Gibney (2008: 165) also discusses the increased efforts by states to realize "nominally voluntary return".

Dutch figures for the period 2005-2011 show a marked increase in deportees and those leaving by way of AVR (Leerkes, Boersema, Galloway, van Os, \& van Londen, 2014). Of all asylum seekers rejected in 2005 not obtaining a residence permit at a later stage, 5.3\% made use of AVR in the calendar year of rejection or the one after, and $0.9 \%$ was deported. By 2011, the cumulative "demonstrable" departure rate was $12.5 \%$. Five cohorts later, among all asylum seekers rejected in $2010,18.3 \%$ had already made use of AVR by 2011 , and $20.5 \%$ had been deported. ${ }^{3}$ These figures raise the question of whether Gibney's "deportation turn" also manifests itself in AVR, and, if so, whether the AVR increases are mostly a by-product of rising deportation rates-which may make migrants prefer AVR over being deported-, or whether other policy mechanisms, which are more specific to AVR, were responsible.

It is against this background that we ask: What explains the increase in AVR in the period 2005-2011 among 6-year cohorts of asylum seekers rejected in the Netherlands in the period 2005-2010? This question is answered using a multilevel dataset with information on (i) Dutch admission and return policies; (ii) source country political and economic conditions; and (iii) asylum seekers' demographic characteristics (age, sex, and family status). The influence of policy factors are estimated, while controlling the effects of two non-policy factors that are generally seen as primarily determining return migration, namely source country societal conditions and migrants' social attachments.

Our interest is in understanding return migration among rejected asylum seekers, and we treat AVR as an indicator of return migration. It should nonetheless be kept in mind that 'non-assisted' (unregistered) return also occurs, and that return may be another step in a complex chain of mobilities (cf. King \& Christou, 2011). While the opportunities for remigration to the Global North seem to be limited for rejected asylum seekers (cf. Van Houte, Siegel, \& Davids, 2015), repatriation does not preclude the possibility of continued migration, especially domestically or regionally.

By estimating the effects of non-policy and policy factors on AVR -regardless of whether these explain the increase in AVR-the analysis also adds to the literature on the determinants of return among rejected asylum seekers. To our knowledge, there are no quantitative studies testing these determinants. The few existing quantitative studies are descriptive (e.g., IOM, 2010), and the insights of qualitative studies (e.g., Black et al., 2004; Kromhout, 2009; Van Houte et al., 2015; Zimmermann, 2010) have never been combined and tested in a multivariate model. There also is a larger literature on return among labor migrants, family migrants, and asylum permit holders migrants (for instance Constant \& Massey, 2002; De Haas \& Fokkema, 2011 De Vroome \& Van Tubergen, 2014; Dustmann \& Weiss, 2007; Jensen \& Pedersen, 2007; Klinthäll, 2007), but it is unclear whether its findings can be generalized to rejected asylum seekers, whose return decisions occur in the context of a significant involvement of governments to realize the return (while restricting remigration). Additionally, the return decisions may depend more on source country political conditions, especially in comparison with labor and family migrants.

The analysis also contributes to the understanding of policy effects in migration studies. While international migration is heavily regulated, there is still a tendency in migration studies, especially in quantitative work, to explain international migration in more or less the same way as domestic migration (e.g., see migration as the outcome of wage differentials, social ties, and so forth). It is increasingly recognized that more attention needs to be given to the role of immigration policy. For example, Massey (2015) set out to develop a "theory of the state", which argues that states mediate the effects of non-policy determinants of migration; policies typically become more restrictive, for example, in periods of economic contraction. What interests us here are the causal mechanisms (Hedström \& Ylikoski, 2010) via which laws and policies, once implemented, codetermine migration patterns. Focusing on AVR among rejected asylum seekers, we aim to contribute to the understanding of various policy mechanisms, the relevance of which is not limited to AVR (coercion, deterrence, facilitation, rewarding, and perceived legitimacy). The latter mechanism in particular has largely been overlooked in the migration literature (but see Ryo, 2013; Van Alphen, Molleman, Leerkes, \& van den Hoek, 2013).

Finally, we aim to contribute to the discussion on terminology. Scholars have criticized the term 'voluntary return' when it characterizes the return of individuals who are unlikely to have returned had they been offered a residence permit (Blitz, Sales, \& Marzano, 2005; Webber, 2011), but no real alternatives have been proposed. We propose the term "soft deportation" as a conceptual tool to transcend the administrative dichotomy of "voluntary" and "forced" return.

\section{2 | NON-POLICY AND POLICY DETERMINANTS OF AVR}

\section{1 | Non-policy factors}

Return migration is partially driven by source country societal conditions, including changes in these conditions. Dustmann and Weiss (2007), for example, show that return rates are lower among migrants originating from poorer countries than among those originating from richer countries. For asylum migrants, economic factors are assumed to be less important than political factors (Black et al., 2004; King, 2000; Van Wijk, 2008), but asylum migrants certainly also have socioeconomic reintegration concerns (Klinthäll, 2007; Zimmermann, 2010).

Return migration is also determined by social attachments. Formal education in the source country, for instance, is generally associated with higher return rates (Constant \& Massey, 2002; Dustmann \& Weiss, 2007; Jensen \& Pedersen, 2007; Klinthäll, 2007). Likewise, return becomes more likely when migrants were employed in their country of origin and/or have ties with partners and children who live there (Constant \& Massey, 2002). It can therefore be expected that AVR is relatively likely among older asylum applicants; source country attachments typically increase with migration age, as individuals have had more time to build up such attachments (Dustmann, Bentolila, \& 
Faini, 1996; Snel, Engbersen \& Leerkes, 2016). Such an age effect is unlikely to be linear: after a certain age, persons become less able-bodied and mobile.

Asylum country attachments can be expected to have a less unequivocal influence. Sociocultural integration is generally found to have a negative effect on return intentions (De Haas \& Fokkema, 2011; De Vroome \& Van Tubergen, 2014). Those who have acculturated to the immigration country may experience return as particularly stressful (Tannenbaum, 2007), and immigrants who identify strongly with the immigration country, and feel at home there, are less inclined to return (Constant \& Massey, 2002). We therefore expect that asylum seekers with children, especially of school age, are relatively unlikely to leave by way of AVR. At school, children learn more about the asylum country and its language, and school-age children spend more time with peers and teachers than with their parents (Kalverboer \& Zijlstra, 2006). Economic integration has a more ambiguous and sometimes positive effect on return (De Haas \& Fokkema, 2011; De Vroome \& Van Tubergen, 2014). However, its effects lie outside the scope of the present study, as there is little variation in economic integration during the asylum procedure (labor market access is restricted).

Migrants also have attachments to immigrant networks in the asylum country, often consisting of (former) compatriots. Ethnic incorporation is especially relevant for individuals lacking legal residence, as it increases the "opportunity structure of illegal residence" (cf. Engbersen, Van San \& Leerkes, 2006; Leerkes, Engbersen \& Van San, 2007): opportunities to find accommodation, informal work, financial support, and potential future spouses able to sponsor family reunification applications. It also reduces apprehension risks (Leerkes, Varsanyi \& Engbersen, 2012).

Asylum migration is generally initiated by men. Often, women apply for asylum once their partners have settled to some degree (Mascini \& Van Bochove, 2009). It can therefore be expected that AVR use among unaccompanied men is more prevalent than among men accompanied by their families. Unaccompanied men, especially if married, will have stronger source country attachments than men in families, and there will also be stronger "settlement intentions" once women and children have migrated. For women, this effect will be less pronounced, for example because unaccompanied women may have fled gender-based family violence (cf. Randall, 2002).

\section{2 | The Dutch "deportation regime"}

Policy factors co-determine migration. Here, we are primarily interested in how AVR-within given legal constructions of certain categories of migrants as "deportable"-is produced by "deportation regimes", a term that we borrow from De Genova (2010), but choose to use in the plural and define more narrowly as: systems of organizing the departure of foreigners from a state's territory who do not, or no longer, have a legal stay there, or are about to lose that right. ${ }^{4}$ Deportation regimes, so defined, have two main dimensions: (1) the infrastructure that states have developed to apprehend and deport migrants who have become deportable and (2) the infrastructure that states have developed-either directly or more indirectly-to seduce, press or convince individuals who are (expected to become) deportable into leaving themselves. The IOM is an intergovernmental organization, and its involvement in the return of rejected asylum seekers can be conceptualized as a form of "remote control" through which (western) governments involve inter-state and non-state actors, such as airline carriers and employers, in migration control (cf. Lahav \& Guiraudon, 2006). We do not take a position as to whether it is good or bad that part of the IOM's activities are an element of deportation regimes so defined.

In order to understand policy effects, it is useful to make a distinction between instrumental and normative models of compliance (Tyler, 2003; Scott, 2008), and, relatedly, between hard power and soft power (Nye, 2004).

Instrumental models explain (non) compliance as arising from selfinterested calculation: due to certain policy interventions, the attractiveness of the proscribed behavior (here: overstaying the "departure term") may or may not become lower than that of an alternative course of action (here: return migration). Instrumental models typically distinguish between "positive" and "negative" mechanisms. In the case of AVR, positive mechanisms include facilitation, that is, the lowering of costs, such as travel costs, and rewarding, that is, increasing the benefits of "desirable" behavior, such as handing over reintegration assistance after returnees have returned. The main negative policy mechanism is deterrence, that is, attempts to increase the costs of "undesirable" behavior (here: overstaying the departure term), for example by reducing rejected asylum seekers' access to labor markets and accommodation, or by increasing deportation risks. Deportation in particular, also requires some degree of force, the ability to obtain an outcome (deportation) without having to rely on the compliance on the part of the subject.

While asylum migrants do not seem to consider financial support an important factor in return decisions (Black et al., 2004), one potentially underestimates how states affect AVR by exclusively focusing on positive "instrumental" mechanisms. Based on interviews with IOM employees and an assessment of their client files, Van Wijk (2008) concludes that it is not unusual for returnees to feel pressured into AVR due to financial problems, unemployment, labor inspections, and a desire to evade immigration detention.

Normative models maintain that rules are followed because people believe that doing so is right or "normal" (compare Andrijasevic and Walters (2010) on the "normalisation of return"). A distinction is usually made between the normative evaluation of outcomes and procedures. Outcome legitimacy means that a rule's content is considered fair or, as neo-institutionalists emphasize (Scott, 2008), simply as "normal", that is, "as the way we do these things". This would mean, for instance, that applicants from relatively safe and free countries choose to return because they recognize that their asylum cases were weak, and that they believe that states have a right to deny a residence permit in such cases. Procedural legitimacy means that rules are enforced in ways that are perceived as just, by actors who are trusted and considered legitimate. Certain procedural aspects of perceived legitimacy are primarily related to how migration admission rules are applied, and we pay attention to one aspect here: the extent to which the asylum decision is likely to be perceived as having been reached carefully after "due process" and after a "fair" amount of time has been spent to assess the claim. In a previous study, we found that the percentage of asylum seekers appealing a negative decision was about $20 \%$ points lower among those rejected between 2 weeks and 3 months than 
among those rejected within 2 weeks, or after more than 3 months (Leerkes et al., 2014). For this reason, we expect a non-linear relationship between status determination time and AVR, with lower probabilities of AVR in case of both "quick" and "slow" negative first instance decisions. Other procedural aspects primarily pertain to the return process. For example, in 2005, the United Kingdom (UK) government began allocating case-workers to asylum seekers who follow the asylum case from beginning to end and are to build up a relationship with them. Gibney (2008: 166) hypothesizes that such relationships potentially "generate[s] in the asylum seeker a feeling of obligation to return home if his or her claim is deemed unfounded."

Nye (2004: 256) has coined the term soft power, which he defines as "the ability to get what you want through [normative] attraction rather than coercion or payments". In Nye's view, coercion (i.e., force and deterrence) and payments (i.e., facilitation and rewarding) constitute hard power, while he classifies the normative, more indirect mechanisms of compliance as soft power: "When our policies are seen as legitimate in the eyes of others, our soft power is enhanced" (ibid). We adopt the idea that harder and softer forms of power exist, but believe it is more appropriate to conceptualize them as lying on a hard-to-soft continuum going from force, deterrence, facilitation/ rewarding, to perceived legitimacy. Deterrence constitutes a harder form of power than payments, as the latter typically leave the subject more choice to comply or resist. While the first dimension of deportation regimes, as defined in the above, puts the emphasis on hard(er) forms of power, the second dimension puts more emphasis on soft(er) forms of power, with the hard(er) forms of power operating in the background.

Three changes in the Dutch deportation regime seem to represent an expansion of hard or soft power, and therefore potentially caused the AVR increase. First, the Netherlands invested considerably in its forced return policy, although this initially was met with little success (Leerkes \& Broeders, 2010). Immigration detention capacity was increased and in 2007, the "Repatriation and Departure Service" (DT\&V) was founded, which became responsible for coordinating the departure of rejected asylum seekers and (other) deportable migrants. It encourages AVR but is especially active in deportation. Deportation rates have indeed gone up after 2007.

Second, the IOM expanded its Randstad Return Programme. Under this program, financed by the Dutch state since 2003, "native counsellors"-IOM employees originating from relevant migrant groups and speaking their language-approach potential returnees living irregularly in the country's largest cities (or are still in asylum seeker centers), and provide information about return programs. The idea behind the program is that migrants are less likely to trust regular Dutch functionaries than functionaries originating from their own country, whom they can meet with repeatedly in an informal setting. By 2010, there were eight counselors. Increased native counselor availability can be expected to have promoted AVR, as it will have increased the perceived procedural legitimacy of the immigration regime. Procedural legitimacy is known to be closely related to trust (see Tyler, 2003).

Third, in the period 2001-2004, reintegration assistance for (rejected) asylum seekers was raised through the "Return and Reintegration Regulation". For example, a couple with two children initially entitled to $f 2150$ (€977) and travel costs became entitled to between $€ 5740$ and $€ 6460$ and travel costs (depending on certain conditions such as whether the departure occurs within the stipulated departure term). ${ }^{5}$ In 2004, it became available to all asylum seekers with the exception of those originating from European Union (EU) member states and other Western countries. Beyond its instrumental effects, increasing reintegration assistance may also have added to perceived procedural legitimacy.

\section{I DATA AND METHOD}

\section{1 | Data}

The Immigration and Naturalisation Service provided individual-level data on all asylum decisions in the 2005-2011 period, including decisions on appeals and repeat applications. Using "foreigner numbers", this information was linked to individual-level information on deportation (by the Immigration and Naturalisation Service and DT\&V) and AVR (by the IOM). The resulting dataset was enriched by adding data at the "country-cohort" level (examples of country cohorts are "China 2005", "China 2006", and "Zimbabwe 2008"), measuring civil freedom, political terror, and standard of living in asylum seekers' countries of citizenship, and characteristics of the Dutch deportation regime (such as whether or not a native counselor was available for the China 2005 cohort).

Not all observations were used. First, we only included individuals who submitted a first application in the years 2005 up to and including 2010. Second, citizens from countries that were or became EU member states in the 2005-2011 period were excluded. Third, those initially rejected who obtained an asylum residence permit at a later stage were filtered out. Fourth, we excluded minors, as we were interested in decision makers. Fifth, if the asylum case involved several adults (those who applied with direct family members could be linked), one adult was randomly selected to remove clustering of observations at the household level (individuals in couples or families will usually not decide on AVR independently from each other). Finally, all cases containing missing values were deleted. Eventually, 15,682 individuals remained. ${ }^{6}$

\section{2 | Dependent and independent variables}

The dependent variable-hereafter: "AVR use"-was dichotomous and indicated whether (1) a person returned with help from IOM in the year he/she was rejected, or the subsequent calendar year or (0) did not return via the IOM in that time span. Some returnees may also have been assisted by nongovernmental organizations, but those who had their travel expenses paid for and used financial reintegration assistance were still registered by IOM (such assistance is exclusively provided by IOM Netherlands). We took the rejection in the first instance, recognizing that those appealing such a rejection may usually await the outcome in the country of asylum: the decision to appeal is not fundamentally different from persons ending up in the 0-category due to overstaying the 28-days departure term, or to illegal migration to a European country. We also ran models predicting AVR use in the year of rejection or the next two calendar years, thereby "losing" the 2010 cohort, yielding similar results (not reported). 
The data were conceptualized as being nested in a three-level structure: individuals are nested in country cohorts, which are nested in countries ("China 2005" and "China 2006", for example, are both, nested in "China"). The 15,682 individuals were nested in 448 country cohorts and 102 different countries.

For all independent variables, the values pertain to the rejection year. The level of civil freedom is by Freedom House, which scores countries annually on their "political rights" and "civil rights" on two 7-point scales, where 1 represents the highest and 7 the lowest level of freedom (i.e., the highest level of "unfreedom"). Political terror was measured using the terror scale by Amnesty International and the United States (US). Department of State, which is coded from 1 (lowest level of political violence and terror) to 5 (highest level). We averaged the figures by Amnesty and the Department of State. As the two Freedom House scales were strongly correlated $(r=0.84)$, and also correlated strongly with political terror $(r=0.57)$, we summed political rights, civil rights and political terror and then deducted 3 , in order to obtain a single scale ranging from 0 to 16 . We measured the change in political unfreedom and terror by subtracting the scores for year $t-1$ from the score for year $t$. Measured changes correspond with meaningful political developments. ${ }^{7}$ Next, standard of living was operationalized as the Gross Domestic Product at purchasing power parity (GDP PPP) per capita, by the World Bank. The variable was skewed to the left (many source countries are quite poor, and there are a few richer countries). The natural logarithm was used, because it resulted in a better model fit and because diminishing returns to living standard can be expected. GDP growth indicated changes in living standard. Ethnic incorporation potential is the number of first-generation immigrants born in country $x$ who were legally present in the Netherlands for at least 2 years in year $t$, divided by the number of asylum seekers with nationality $x$ who were rejected in year $t$. The variable was highly skewed, and the natural logarithm was taken, because it led to a better model fit and because diminishing returns to incorporation potential can be expected.

Four "policy variables" were measured at the country-cohort level. First, all individuals with native counselor access received a ' 1 ' on the dummy native counselor. ${ }^{8}$ Second, deportation risk was defined as the percentage of persons with nationality $x$ rejected in year $t$ and deported in $t$ or $t+1$ (numerator), divided by all persons with nationality $x$ rejected in year $t$ not returning via AVR in $t$ or $t+1$ (denominator). Third, as an indirect measure on financial assistance, we calculated a dummy indicating whether or not the asylum seeker was from Macedonia, Belarus, or Georgia. As was explained in Section 2, the IOM began providing additional financial support in 2004. Given this timing it was impossible to test whether additional support caused the AVR increase, as rejected asylum seekers from all major source countries qualified. However, the Dutch state began to suspect that part of the increase was due to nationals from certain Eastern European countries-from where it is relatively easy to reach Western Europe (as from 2010, Macedonians no longer require a visa to enter the Schengen area)-applying for asylum in order to profit from the increased assistance. Because of these suspicions, three nationalities were excluded from the Return and Reintegration Regulation program in 2010 (Georgia and Macedonia) and 2011 (Belarus). We attempted to "test" this by investigating whether the AVR increase was due to a peak in Macedonians, Georgians, and Belarussians. Fourth, we measured the country-specific real value of financial return assistance, operationalized as the multiplicative inverse of the World Bank's "purchasing power conversion factor" (indicating a country's price level compared with the concurrent U.S. price level), divided by the average US\$ to € exchange rate in that year (return assistance is in Euros). It indicates how much more (or less) could be bought with reintegration assistance in the asylum seeker's source country compared with what it could buy in the US. ${ }^{9}$ For example, a value of 4 indicates that it would buy four times more goods and services there than in the US. This measure takes into account that the real value of return assistance varies by country and year: nominally, financial reintegration assistance is the same for all countries, and is not indexed.

Because of the mostly administrative nature of the data, theoretical concepts varying at the individual-level (social attachments and perceived procedural legitimacy of the first instance rejection) had to be measured indirectly. The following variables were used: age, family status, and status determination time. Family status is a nominal variable, coded from a higher expected AVR probability because of relatively strong source country attachments to a lower expected AVR probability because of weaker source country and stronger asylum country attachments: (1) unaccompanied man, (2) applicant in a childless couple, (3) unaccompanied woman (4) applicant accompanied by one or more child(ren) who are not of school age, (5) applicant accompanied by at least one school-age child. Children between 4 and 16 years of age at the time of the rejection were defined as being of school age. Status determination time is the number of months between the asylum application date and the first instance rejection date.

We experimented with the variable "geographical distance to the Netherlands", but eventually dropped it. It did not have a significant effect, and its theoretical rationale is not unequivocal. ${ }^{10}$ Unemployment data could not be used because there were missing values for too many countries.

\section{3 | Method}

Using Stata, we estimated (random intercept) hierarchical logistical regression models with three levels. Multilevel regression was employed to address clustering of observations at the country cohort (null model ICC: 0.10) and country level (ICC: 0.18). We do not find evidence for multicollinearity. ${ }^{11}$

We first estimated models predicting AVR use regardless of whether the rejected asylum seeker was deported (meaning that those deported in the year of rejection or the subsequent year were included in the 0-category). However, in order to estimate the effects of deportation risk, it was necessary to run comparable models while excluding all individuals who were deported in the year of rejection or the subsequent year. ${ }^{12}$ The latter models only pertain to larger country-cohorts ( $N>50$ )-involving 10,391 individuals, 81 country cohorts and 24 countries-as the reliability of the deportation risk measure is low for smaller cohorts.

We first estimated models only including dummy variables indicating the cohort (year of rejection). Subsequently, it was examined how the coefficients of these dummies changed when assumed AVR 
determinants were added. Coefficients that are both X- and Y-standardized were calculated in order to better compare effect sizes of variables within and between logistic regression models (cf. Mood, 2010).

\section{4 | RESULTS}

\section{1 | Descriptives}

Table 1 gives descriptive statistics. It shows that the AVR increase mainly occurred amongst the cohorts following the 2007 cohort. Rejected asylum seekers were, on average, required to return to countries with political unfreedom and terror levels between 9.9 (2010) and 11.8 (2008; the Netherlands scored 0), and where GDP PPP per capita was, on average, in the $\$ 4000$ to $\$ 5000$ range (about eight times lower than in the Netherlands). Unfreedom and terror vary from cohort to cohort, but GDP per capita shows an upward trend. On average, those included in the dataset were about 30 years old, and over three fourths were unaccompanied men. The number of persons applying for asylum with children fluctuated, but remained in the $7-15 \%$ range for all cohorts. On average, rejected asylum seekers had between 172 (2009) and 323 (2007) relatively established (former) compatriots in the Netherlands.
Turning to the "policy" variables, deportation risk increased sharply from 2007 onwards. In 2005, 3.9\% had access to a native counselor, increasing to $23.1 \%$ for the 2010 cohort. Macedonians, Belarussians and Georgians suddenly represented $20.7 \%$ of all rejected asylum seekers in 2010-without a human rights crisis occurring in these countries-, and $39 \%$ of them returned with IOM aid before 2012 (figure not included in the table). The average time required for the determination of status was about 6 months for most cohorts. ${ }^{13}$ The real value of reintegration assistance shows a downward trend.

\section{2 | Regression analyses}

Table 2 present five regression models (unstandardized effects are given in odds ratios, and XY-standardized effects are given between parentheses). The first model estimates cohort effects without taking account of any other variables. It basically shows the same as Table 1: being in the 2010 cohort is associated with almost three times higher odds on AVR use compared with the 2005 cohort.

Model 2 adds the "non-policy" variables. The level of political unfreedom and terror has a negative coefficient, but is only significant at the $p=0.1$ level in Models 5 and 6. Changes in unfreedom and terror are significant, indicating that AVR use becomes more likely when source country political conditions have recently improved. Standard

TABLE 1 Average values (in)dependent variables by cohort ${ }^{\mathrm{a}}$

\begin{tabular}{|c|c|c|c|c|c|c|}
\hline & \multicolumn{6}{|c|}{ Cohorts } \\
\hline & 2005 & 2006 & 2007 & 2008 & 2009 & 2010 \\
\hline \multicolumn{7}{|l|}{ Dependent variable } \\
\hline \multicolumn{7}{|l|}{ Independent variables: non-policy factors } \\
\hline \multicolumn{7}{|l|}{ Country-cohort level } \\
\hline GDP PPP per capita & $\$ 4,274$ & $\$ 4,401$ & $\$ 5,294$ & $\$ 5,033$ & $\$ 4,251$ & $\$ 4,745$ \\
\hline GDP growth & $6.9 \%$ & $7.5 \%$ & $7.6 \%$ & $6.9 \%$ & $3.7 \%$ & $4.9 \%$ \\
\hline Ethnic incorporation potential & 301 & 207 & 323 & 254 & 172 & 225 \\
\hline \multicolumn{7}{|l|}{ Individual level } \\
\hline Unaccompanied woman & $13.9 \%$ & $12.3 \%$ & $15.8 \%$ & $14.0 \%$ & $12.4 \%$ & $14.8 \%$ \\
\hline Applicant (single or in couple) with children of non-school age & $4.2 \%$ & $3.1 \%$ & $3.8 \%$ & $3.9 \%$ & $4.2 \%$ & $7.1 \%$ \\
\hline Applicant (single or in couple) with at least one school-age child & $5.2 \%$ & $5.8 \%$ & $7.6 \%$ & $3.4 \%$ & $4.3 \%$ & $10.0 \%$ \\
\hline \multicolumn{7}{|l|}{ Independent variables: policy factors } \\
\hline \multicolumn{7}{|l|}{ Country-cohort level } \\
\hline Native counselor availability & $4.6 \%$ & $41.5 \%$ & $26.2 \%$ & $50.9 \%$ & $54.4 \%$ & $23.1 \%$ \\
\hline Real value return assistance & 4.5 & 4.4 & 3.9 & 3.4 & 3.9 & 3.0 \\
\hline Georgian, Macedonian or Belarussian & $9.5 \%$ & $4.9 \%$ & $4.3 \%$ & $2.1 \%$ & $3.1 \%$ & $20.7 \%$ \\
\hline Deportation rate in year of rejection or subsequent year & $1.4 \%$ & $2.8 \%$ & $11.6 \%$ & $17.7 \%$ & $13.9 \%$ & $21.2 \%$ \\
\hline
\end{tabular}

Note. AVR = Assisted Voluntary Return; GDP PPP $=$ Gross Domestic Product at purchasing power parity.

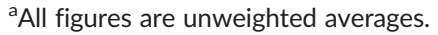


TABLE 2 Odds ratios and XY-standardized coefficients (in parentheses). Dependent variable: AVR use in rejection year or subsequent calendar year

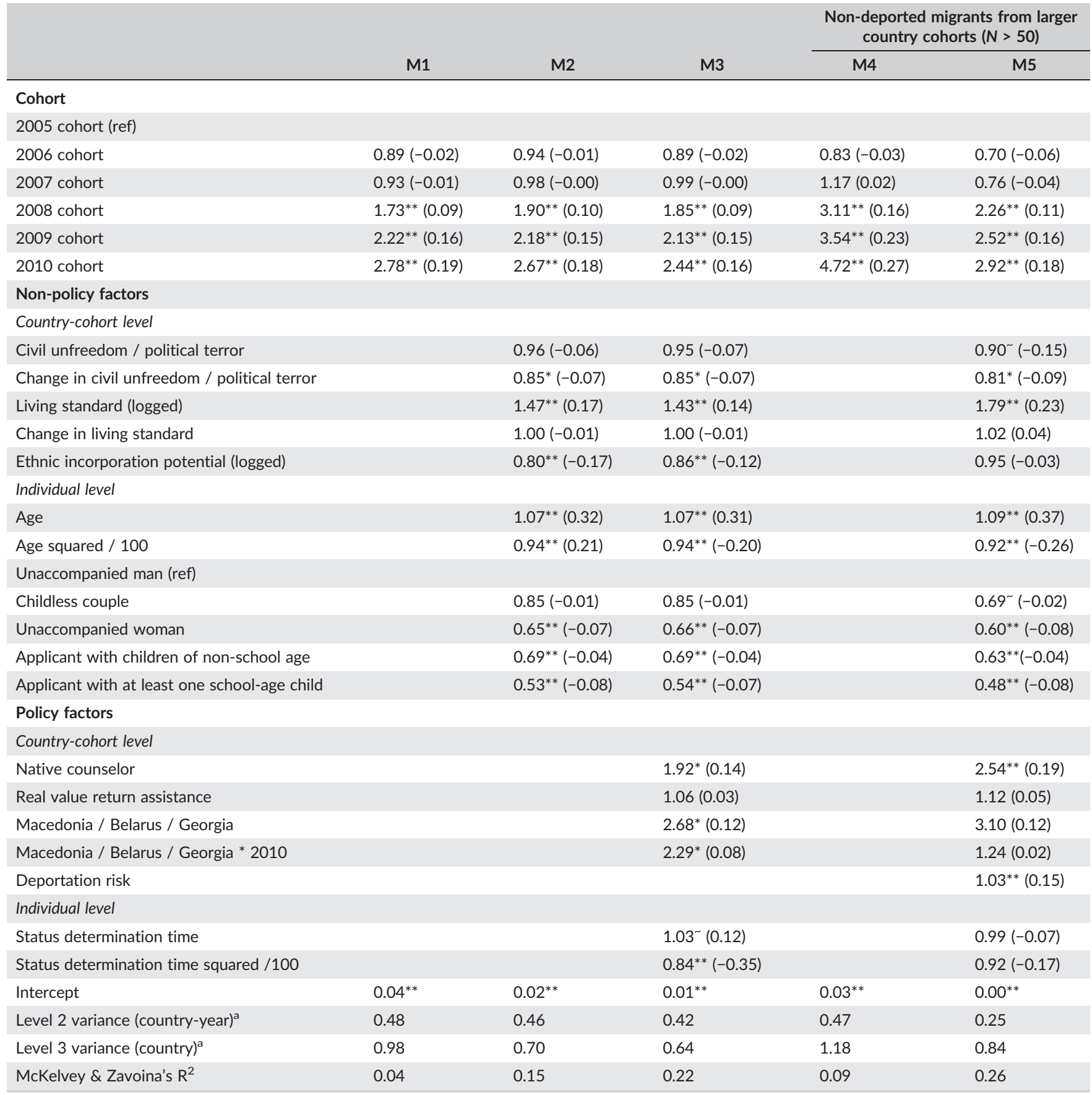

Note. $\mathrm{AVR}=$ Assisted Voluntary Return .

${ }^{* *} p<0.01$

${ }^{*} p<0.05$

$\sim p<0.10$.

aLevel 1 variance is fixed at 3.29

of living has a positive effect: if the logarithm of GDP PPP per capita increases by 1 (roughly the difference between Angola and Lebanon or Ethiopia and Iraq), the odds of AVR use increase by 1.47. Changes in living standard are not significant. Unaccompanied men are more likely to use AVR than couples, unaccompanied women, and those with children, especially with school-age children. There is a curvilinear relationship between age and AVR use: with other factors held constant, it peaks around the age of 60 .
The inclusion of these "non-policy" variables leads to smaller differences between the cohorts: the standardized coefficient for being in the 2010 cohort decreases from 0.192 to 0.181 , a decrease of $6 \%$. Further analyses (not shown) indicate that the coefficients primarily change due to the GDP per capita variable.

The third model adds all "policy" variables, except deportation risk. Net of other factors, native counselor availability almost doubles the odds of AVR use $(p<0.05)$. The coefficient of the real value of 
reintegration assistance is positive, but not significant. ${ }^{14}$ With other factors held constant, Georgians, Macedonians, or Belarussians had almost three times higher odds of AVR use, especially when rejected in 2010 (the interaction with the 2010 dummy is significant). As expected, status determination time shows a curvilinear relationship with AVR use: it first becomes more likely the longer it takes for status to be determined, peaking at an "optimum" of about 7 months, after which it becomes less likely.

Due to the inclusion of the "policy variables", the coefficients of the cohort dummies decrease further. The standardized coefficient for being in the 2010 cohort decreases by $10 \%$, from 0.181 to 0.163 . Further analyses (not shown) indicate that the coefficients mostly change because of increased native counselor availability and the increase in Macedonians, Belarussians and Georgians.

Models 4 and 5 pertain to individuals from cohorts consisting of at least 50 persons who were not deported in the rejection year or the subsequent year. Model 4 only includes the cohort dummies; model 5 includes all variables. The patterns are comparable with the previous models, but ethnic incorporation potential and status determination time are no longer significant. Deportation risk has a significant positive effect on AVR use: a 10\% increase in deportation risk increases the odds of AVR use by about one third $(\exp (10 * \ln (1.031))=1.36)$. The standardized coefficient for the 2010 dummy diminishes from 0.27 to 0.18 (34\%), indicating that among larger cohorts, about a third of the increase in AVR has been explained. Similar results were found when 25 or 75 was taken as the minimum country-cohort size (selecting larger country-cohorts increasingly leads to a loss of statistical power, as few cases remain).

\section{5 | CONCLUSION AND DISCUSSION}

There has been a marked increase in AVR in the Netherlands, and this paper analyses its causes, paying attention to both "non-policy" and "policy" factors. Part of the increase is found to be related to three policy factors: increased "native counselor" availability, heightened deportation risks, and increased financial reintegration support. The evidence for the third factor is indirect and its effects also occurred in unintended ways, as reintegration support actually began to attract migrants from poorer European countries who returned in relatively high numbers using IOM aid. Part of the increase is associated with non-policy factors: on average, the more recent cohorts originated from somewhat more prosperous source countries than the older cohorts. About two thirds of the increase remains unexplained. Given its timing, and other factors being accounted for, we suspect a relationship with the DT\&V case workers being systematically assigned to rejected asylum seekers after 2007.

This study is the first to quantitatively test assumed AVR determinants and generalizability of known determinants of return migration among labor, family, and asylum permit holders. Various assumed determinants, including those not explaining the AVR increase, were corroborated. First, source country political conditions do not only matter during admission decisions, but also influence the return decisions among those who are not considered to be in need of protection. Second, such decisions are driven by economic considerations, with return to unprosperous countries being relatively uncommon. Third social attachments matter: age of migration-indicating source country attachments-has a curvilinear effect on AVR, with rates peaking around the age of 60; families, especially those with school-age children, are relatively unlikely to return. Opportunities for ethnic incorporation diminish return migration.

In the remainder of the article, we go into the study's broader implications for the (1) debate on terminology and (2) the study of policy effects in migration studies.

(1) Return migration has different meanings to different migrants. However, rather than "voluntary" and "forced" return being a simple dichotomy, practices of return lie on a continuum, from relatively voluntary to relatively forced, and we usually observe complex blends of (in)voluntariness. Even relatively privileged migrants conducting return visits as part of a "voluntary" transnational lifestyle (Erdal, Amjad, Bodla, \& Rubab, 2016), may partially be pressured into transnational living by the challenges of integration (Snel, 't Hart, \& Van Bochove, 2016). At the other end of the continuum, in case of "forced return", we still find immigration detainees consenting to their deportation, while others successfully use their agency to resist it (Hasselberg, 2014; Lietaert, Broekaert, \& Derluyn, 2015; Leerkes \& Kox, 2016).

The mere lack of force is insufficient to frame AVR as being on the "voluntary" side of this spectrum. On the one hand, our analysis does indicate some voluntariness in the sense that those who are known to be relatively likely to return-such as citizens from more prosperous countries who have relatively strong source country attachments-are overrepresented among the IOM's clients. Furthermore, the return is partly the result of "softer" forms of power, such as perceived legitimacy, which leave people some choice to comply or resist. On the other hand, it is clear that rejected asylum seekers are typically required to return to countries that are unattractive destinations for return migration. It is questionable whether they would have returned had they obtained a residence permit and had not been put at risk of deportation. In other words, while voluntariness, facilitation, and mechanisms contributing to the perceived legitimacy of return are foregrounded in AVR, deterrence and force certainly operate in the background.

One possibility to overcome legal dichotomies and do more justice to the properties of return migration among non-deported rejected asylum seekers, is by seeing it as a form of "soft deportation" (or "soft expulsion"), reserving the term (hard) "deportation" to forced removal: this sensitizes us to the fact that such return has deportation-like properties, while acknowledging that it depends less on force and deterrence, and more on perceived legitimacy and-should the return be "assisted"-on payments. While we do not expect policymakers and the IOM to adopt the term, one wonders why the adjective "voluntary" in AVR isn't simply dropped. The term "soft deportation" is not intended to capture all AVR variants and all forms of return involving unauthorized migrants: there may be significantly more voluntariness in assisted return among asylum permit holders and among illegally staying labor migrants who choose to return after they have successfully saved up enough capital ('target earners").

(2) As the Dutch state does not register unassisted departure, AVR increases could be due to "substitution", to the effect that those who had in the past returned on their own increasingly began returning 
with IOM. If unregistered departure was indeed relatively uncommon -especially in the form of return rather than onward migration to a different European country-there will have been a real increase in return. ${ }^{15}$ With that proviso, our findings confirm Gibney's (2008) argument on effective policy innovation: the AVR increases were a by-effect of the rising deportation rates and were driven by policy mechanisms that are more specific to AVR, most notably the increased use of "native counsellors" (and possibly the DT\&V case workers).

States only seem to be capable or partially closing "efficacy gaps" (Czaika \& De Haas, 2013) in the return of asylum seekers. Even for the 2010 cohort, less than $50 \%$ left the country "demonstrably" by 2012 , suggesting that many individuals still preferred the curtailed life chances as unauthorized migrants to a return to the source country conditions that they fled. International inequality-both in living standard, safety and freedom-clearly acts as a powerful counterforce, limiting the efficacy of deportation regimes. Ethnic incorporation opportunities similarly generate a kind of "cumulative causation" (Massey, 1990) effect in asylum migration that is difficult for states to control.

The attention being paid to policy gaps in migration studies should not divert scholarly attention away from what laws and policies do achieve, and how this occurs, that is, not only via "visible" policy mechanisms (force, facilitation, and highly visible forms of deterrence), but also via more "invisible" mechanisms, including forms of deterrence resulting from the exclusion of unauthorized migrants from labor markets and social provisions, and, especially, perceived legitimacy. While the legitimacy of today's immigration regimes is far from uncontested (also see Ryo, 2013), we suspect that perceived legitimacy still limits international migration considerably, if only because political borders are likely to have the effect of international migration being perceived as less "natural" and "allowed" than domestic migration. A direction for future research on policy effects would be to better understand such mechanisms, and to examine whether cultural developments under the influence of globalization, including the possible rise of an aspired "global citizenship" in countries outside of the Global North, attenuate such normative influences on migration patterns.

\section{ENDNOTES}

1 The amnesty involved asylum seekers registered before April 2001, and resulted in about 30,000 residence permits. The asylum applications of about 100,000 persons (aged 12 years or older) who applied between January 1995 and April 2001 were rejected (De Boom, Engbersen, \& Leerkes, 2006). Assuming that about $20 \%$ of them left through AVR or deportation, about $0.80 * 100,000=80,000$ persons remained who, on average, had 9 years to leave the country after the rejection of their asylum claim until the Amnesty. If 30,000 were in the country in 2007 , then 50,000 must have left, suggesting an average annual departure rate of $6.9 \%(50,000 / 80,000 / 9 * 100 \%)$. Indeed, in a sample of 108 nearly rejected asylum seekers no more than $8 \%$ scored higher than 4 on a 1 to 7 Likert scale measuring intention to return in the next 12 months, including non-assisted return, and no less than $78 \%$ scored a 1 (Leerkes, Galloway \& Kromhout, 2010).

2 Since the 1997 Dublin Convention entered into force, rejected asylum seekers applying for asylum elsewhere in Europe can be returned to the country of the first asylum application. Since EURODAC became operational in 2003, they are recognized by their finger prints. Other intergovernmental "foreigner" databases also expanded.

\footnotetext{
3 These figures pertain to individuals included in the present analyses.
}

4 This notion of deportation is broader than in a strictly legal sense: deportation regimes, so defined, also encompass all activities by, on behalf of, or promoted by governments to encourage the "voluntary" return of foreigners who become deportable should they stay. It is narrower than De Genova's (2010) conceptualization, who considers 'deportability'-which also pertains to how individuals may become defined as deportable - an important aspect of "the" deportation regime (he only uses the term in the singular). We are hesitant to consider such definitional aspects as elements of deportation regimes; it seems more appropriate to regard them as belonging to countries' admission or citizenship regimes.

5 Parliamentary Papers II 2001/2002, 19637/26646, no. 609; and http:// www.iom-nederland.nl/nl/vrijwillig-vertrek/terugkeer-naar-uw-landvan-herkomst-rean, visited July 2014.

6 In the 2005-2011 periods, 39,132 individuals received a negative first instance decision. After deleting minors and randomly selecting one individual in files containing several adults, 27,710 persons remained. A total of 22,413 persons remained after selecting non-EU nationals with a first instance decision before 2011 (leaving out the 2011 cohort). A total of 17,801 persons remained after removing cases with missing values on any of the independent variables ( 22 died according to registrations). Finally, about 2000 persons were excluded who submitted a first asylum request before 2005 , as it could not be established with certainty for them whether the first registered decision in the 20052011 period really was the first negative decision. Missing values were partly due to a lack of information on the country-cohort level (mostly on GDP and/or price level), such as for Somalia and Cuba. The AVR rates for these countries were usually relatively low and their exclusion led to slightly higher AVR rates (11.5\% on average for the 2005-2011 cohorts, instead of $9.5 \%)$.

7 For example, in 2010, Guinea held elections after a military coup ( -5 on our measure), in 2006, the Nepalese king reinstated the dissolved House of Representatives (-2.5), in 2009, U.S. troops handed over security duties to Iraqi forces (-1.5), and in 2006, the Tamil tigers and the Sri Lankan government resumed fighting $(+2.5)$.

8 Only asylum seekers with the same national origin as a native counselor received a 1 on the dummy, even if some counselors serve larger language regions, such as "the Maghreb".

9 The degree of inflation in the United States compared with 2005 was adjusted for (the 2006 rates were divided by 1.032, e.g., as the U.S. inflation rate for 2006 was 3.2\%).

10 Usually, there is more temporary migration between nearby countries. However, due to higher transportation costs, returnees from far away countries have a larger incentive to use AVR instead of financing the return themselves. These mechanisms may offset each other.

11 Using the Stata collin package, we found Variance Inflaction Factor (VIF) values to be under 3.4 in all models, except for the squared terms "age" (VIF $\approx 22$ ) and "status determination time" (VIF $\approx 8$ ). (Squared terms are highly correlated by definition). The highest correlation $(r=0.52)$ was found between native counselor and political unfreedom and terror.

12 If deportees are kept in the 0-category, the effects of deportation risk are underestimated: the elevated number of AVR users among country-cohorts with many deportees would be masked by an overestimation of the number of people not leaving.

13 Average status determination time is short for the 2005 cohort, because only persons with a first application after 2005 are included.

14 Countries with low price levels may be unattractive destinations beyond "GDP PPP per capita" and "unfreedom and terror" values. Future research should look into such possible "unmeasured heterogeneity".

15 We also find increases in AVR if we limit the analysis to relatively distant countries where migrants are more unlikely to have returned to without assistance due to higher transportation costs.

\section{REFERENCES}

Andrijasevic, R., \& Walters, W. (2010). The International Organization for Migration and the international government of borders. Environment and Planning D: Society and Space, 28(6), 977-999. doi:10.1068/d1509 
Baldaccini, A. (2009). The return and removal of irregular migrants under EU law: An analysis of the returns directive. European Journal of Migration and Law, 11(1), 11-17. doi:10.1163/157181609X410566

Black R., Koser R. K., Munk K., Atfield G., D'Onofrio L., \& Tiemokoet R. (2004). Understanding voluntary return, Online Report 50/04. Home Office, London.

Blitz, B., Sales, R., \& Marzano, L. (2005). Non-voluntary return? The politics of return to Afghanistan. Political Studies, 53(1), 182-200. doi:10.1111/ j.1467-9248.2005.00523.x

Constant, A., \& Massey, D. (2002). Return migration by German guestworkers: Neoclassical versus new economic theories. International Migration, 40(4), 5-38. doi:10.1111/1468-2435.00204/

Czaika, M., \& De Haas, H. (2013). The Effectiveness of immigration policies. Population and Development Review, 39(3), 487-508. doi:10.1111/ j.1728-4457.2013.00613.x

De Boom, J., Engbersen, G., \& Leerkes, A. (2006). Asielmigratie en criminaliteit. Apeldoorn: Politie en Wetenschap.

De Genova, N. (2010). The deportation regime: Sovereignty, space and the freedom of movement. In N. De Genova, \& N. Peutz (Eds.), The Deportation Regime. (pp. 33-65). Durham, NC: Duke University Press.

De Haas, H., \& Fokkema, T. (2011). The effects of integration and transnational ties on international return migration intentions. Demographic Research, 25(4), 755-782. doi:10.4054/DemRes.2011.25.24.

De Vroome, T., \& Van Tubergen, F. (2014). Settlement intentions of recently arrived immigrants and refugees in the Netherlands. Journal of Immigrant \& Refugee Studies, 12(1), 47-66. doi:10.1080/ 15562948.2013.810798

Dustmann, C., \& Weiss, Y. (2007). Return migration: Theory and empirical evidence from the UK. British Journal of Industrial Relations, 45(2), 236-256. doi:10.1111/j.1467-8543.2007.00613.x

Dustmann, C., Bentolila, S., \& Faini, R. (1996). Return migration: The European experience. Economic Policy, 11(22), 213-250. doi:10.2307/ 1344525

Ellermann, A. (2008). The limits of unilateral immigration control: Deportation and inter-state cooperation. Government and Opposition, 43(2), 168-189. doi:10.1111/j.1477-7053.2007.00248.x

Engbersen, G., van San, M., \& Leerkes, A. (2006). A room with a view. Illegal immigrants in the legal capital of the world. Ethnography, 7(2), 209-242. doi:10.1177/1466138106067057

Erdal, M. B., Amjad, A., Bodla, Q., \& Rubab, A. (2016). Going back to Pakistan for education? The interplay of return mobilities, education and transnational living. Population, Space and Place, 22(8), 836-848. doi:10.1002/psp.1966

Gibney, M. (2008). Asylum and the expansion of deportation in the United Kingdom. Government and Opposition, 43(2), 146-167. doi:10.1111/ j.1477-7053.2007.00249.x

Hasselberg, I. (2014). Coerced to leave: Punishment and the surveillance of foreign-national offenders in the UK. Surveillance \& Society, 12(4), 471-484. doi:10.2139/ssrn.2600617

Hedström, P., \& Ylikoski, P. (2010). Causal mechanisms in the social sciences. Annual Review of Sociology, 36(1), 49-67. doi:10.1146/ annurev.soc.012809.102632

INDIAC. (2007). Cohortanalyse asielprocedure 2001-2006. Rijswijk: Ministry of Justice.

IOM (International Organization for Migration). (2010). Assisted Voluntary Return from the Netherlands: An analysis of fluctuations in AVR participation (1992-2008). The Hague: International Organization for Migration.

Jensen, P., \& Pedersen, P. (2007). To stay or not to stay? Out-migration of immigrants from Denmark. International Migration, 45(5), 87-113. doi:10.1111/j.1468-2435.2007.00428.x

Kalverboer, M., \& Zijlstra, A. (2006). De schade die kinderen oplopen als zij na langdurig verblijf in Nederland gedwongen worden uitgezet. Groningen: Rijksuniversiteit Groningen.
King, R. (2000). Generalizations from the history of return migration. In B. Ghosh (Ed.), Return migration: Journey or hope or despair? (pp. 1-18). Geneva: IOM/ UNHCR.

King, R., \& Christou, A. (2011). Of counter-diaspora and reverse transnationalism: return mobilities to and from the ancestral homeland. Mobilities, 6(4), 451-466. doi:10.1080/17450101.2011.603941

Klinthäll, M. (2007). Refugee return migration: Return migration from Sweden to Chile, Iran and Poland 1973-1996. Journal of Refugee Studies, 20(4), 579-598. doi:10.1093/jrs/fem029

Kromhout, M. (2009). Return of separated children: The impact of Dutch policies. International Migration, 49(5), 24-47. doi:10.1111/j.14682435.2009.00587.x

Lahav, G., \& Guiraudon, V. (2006). Actors and venues in immigration control: Closing the gap between political demands and policy outcomes. West European Politics, 29(2), 201-223. doi:10.1080/01402380500512551

Leerkes, A., Boersema, E., Galloway, M., van Os, R., \& van Londen, M. (2014). Afgewezen en uit Nederland vertrokken? Een onderzoek naar de achtergronden van variatie in zelfstandige terugkeer onder uitgeprocedeerde asielzoekers. The Hague: WODC.

Leerkes, A., \& Broeders, D. (2010). A case of mixed motives? Formal and informal functions of administrative immigration detention. British Journal of Criminology, 50(5), 830-850. doi:10.1093/bjc/azq035

Leerkes, A., Engbersen, G., \& van San, M. (2007). Shadow places. Patterns of spatial concentration and incorporation of irregular immigrants in the Netherlands. Urban Studies, 44(8), 1491-1516. doi:10.1080/ 00420980701373479

Leerkes, A., Galloway, M., \& Kromhout, M. (2010). Kiezen tussen twee kwaden. Determinanten van blijf-en terugkeerintenties onder (bijna) uitgeprocedeerde asielmigranten. The Hague: WODC.

Leerkes, A., \& Kox, M. (2016). Pressured into deportation? Detainees' (un) willingness to 'return' and the moderating influence of international relations. In R. Furman, D. Epps, \& G. Lamphear (Eds.), Detaining the immigrant other. Global and transnational issues. (pp. 15-16). New York: Oxford University Press.

Leerkes, A., Varsanyi, M., \& Engbersen, G. (2012). Local limits to migration control: Practices of selective migration policing in a restrictive national policy context. Police Quarterly, 15(4), 446-475. doi:10.1177/ 1098611112453719

Lietaert, I., Broekaert, E., \& Derluyn, I. (2015). The lived experiences of migrants in detention. Population Space and Place, 21(6), 568-579. doi:10.1002/psp.1861

Mascini, P., \& Van Bochove, M. (2009). Gender stereotyping in the Dutch asylum procedure: 'independent' men versus 'dependent' women. International Migration Review, 43(1), 112-133. doi:10.1111/j.01979183.2008.01149.x

Massey, D. (1990). Social structure, household strategies, and the cumulative causation of migration. Population Index, 56(1), 3-26. doi:10.2307/3644186

Massey, D. (2015). A missing element in migration theories. Migration Letters, 12(3), 279-299.

Mood, C. (2010). Logistic regression: Why we cannot do what we think we can do, and what we can do about it. European Sociological Review, 26(1), 67-82. doi:10.1093/esr/jcp006

Noll, G. (1999). Rejected asylum seekers: the problem of return. International Migration, 37(1), 267-288. doi:10.1111/14682435.00073

Nye, J. (2004). Soft power and American foreign policy. Political Science Quarterly, 119(2), 255-270. doi:10.2307/20202345

Randall, M. (2002). Refugee law and state accountability for violence against women: a comparative analysis of legal approaches to recognizing asylum claims based on gender persecution. Harvard Women's Law Journal, 25, 281-318.

Ryo, E. (2013). Deciding to cross. Norms and economics of unauthorized migration. American Sociological Review, 78(4), 574-631. doi:10.1177/ 0003122413487904 
Scott, R. (2008). Approaching adulthood: The maturing of institutional theory. Theory and Society, 37(5), 427-442. doi:10.1007/s11186-008-9067-z

Snel, E., Engbersen, G., \& Leerkes, A. (2016). Transnational involvement and social integration. Global Networks, 6(3), 285-308. doi:10.1111/j.14710374.2006.00145.x

Snel, E., 't Hart, M., \& Van Bochove, M. (2016). Reactive transnationalism: Homeland involvement in the face of discrimination. Global Networks, 16(4), 511-530. doi:10.1111/glob.12125

Tannenbaum, M. (2007). Back and forth: Immigrant's stories of migration and return. International Migration, 45(5), 147-175. doi:10.1111/ j.1468-2435.2007.00430.x

Tyler, T. (2003). Procedural justice, legitimacy, and the effective rule of law. Crime and Justice, 30, 283-357. doi:10.1086/652233

van Alphen, B., Molleman, T., Leerkes, A., \& van den Hoek, J. (2013). Van bejegening tot vertrek. Een onderzoek naar de werking van vreemdelingenbewaring. The Hague: Boom Lemma.

Van Houte, M., Siegel, M., \& Davids, T. (2015). Return to Afghanistan: Migration as reinforcement of socio-economic stratification. Population, Space and Place, 21(8), 692-703. doi:10.1002/psp.1876
Van Wijk, J. (2008). Reaching out to the unknown: Native counseling and the decision making process of irregular migrants and rejected asylum seekers on voluntary return. The Hague: IOM.

Webber, F. (2011). How voluntary are voluntary returns? Race and Class, 52(4), 98-107. doi:10.1177/0306396810396606

Zimmermann, S. (2010). Understanding repatriation: Refugee perspectives on the importance of safety, reintegration, and hope. Population, Space and Place, 18(1), 45-57. doi:10.1002/psp.647

How to cite this article: Leerkes A, van Os R, Boersema E. What drives 'soft deportation'? Understanding the rise in Assisted Voluntary Return among rejected asylum seekers in the Netherlands. Population Space Place. 2017. doi: 10.1002/ psp.2059 